\title{
Novel Chlamydiales genotypes identified in ticks from Australian wildlife
}

\author{
Delaney Burnard ${ }^{1}$, Haylee Weaver ${ }^{2}$, Amber Gillett ${ }^{3}$, Joanne Loader ${ }^{4}$, Cheyne Flanagan ${ }^{5}$ and Adam Polkinghorne ${ }^{1^{*}}$
}

\begin{abstract}
Background: Members of the order Chlamydiales are known for their potential as human and veterinary bacterial pathogens. Despite this recognition, epidemiological factors such as routes of transmission are yet to be fully defined. Ticks are well known vectors for many other infections with several reports recently describing the presence of bacteria in the order Chlamydiales in these arthropods. Australian wildlife are hosts to an extensive range of tick species. Evidence is also growing that the marsupial hosts these ticks parasitise can also be infected by a number of bacteria in the order Chlamydiales, with at least one species, Chlamydia pecorum, posing a significant conservation threat. In the current study, we investigated the presence and identity of Chlamydiales in 438 ixodid ticks parasitizing wildlife in Australia by screening with a pan-Chlamydiales specific targeting the 16S rRNA gene.

Results: Pan-Chlamydiales specific PCR assays confirmed the common presence of Chlamydiales in Australian ticks parasitising a range of native wildlife. Interestingly, we did not detect any Chlamydiaceae, including C. pecorum, the ubiquitous pathogen of the koala. Instead, the Chlamydiales diversity that could be resolved indicated that Australian ticks carry at least six novel Chlamydiales genotypes. Phylogenetic analysis of the $16 \mathrm{~S}$ rRNA sequences (663 bp) of these novel Chlamydiales suggests that three of these genotypes are associated with the Simkaniaceae and putatively belong to three distinct novel strains of Fritschea spp. and three genotypes are related to the "Ca. Rhabdochlamydiaceae" and putatively belong to a novel genus, Rhabdochlamydia species and strain, respectively.

Conclusions: Sequence results suggest Australian wildlife ticks harbour a range of unique Chlamydiales bacteria that belong to families previously identified in a range of arthropod species. The results of this work also suggest that it is unlikely that arthropods act as vectors of pathogenic members of the family Chlamydiaceae, including C. pecorum, in Australian wildlife. The biology of novel Chlamydiales identified in arthropods remain unknown. The pathogenic role of the novel Chlamydiales identified in this study and the role that ticks may play in their transmission needs to be explored further.
\end{abstract}

Keywords: Chlamydia, Chlamydia-like organisms, Ticks, Marsupials, Wildlife, Transmission, Vector, Australia

\section{Background}

Bacteria of the order Chlamydiales are obligate intracellular parasites. Many of the best described members of this order belong to the traditional family Chlamydiaceae, well known for causing significant disease in humans and a variety of domesticated and wild animals [1]. Outside of this family, four other families are taxonomically recognised in this order, the Waddliaceae, Parachlamydiaceae, Criblamydiaceae and Simkaniaceae [2-4]. There is also a

\footnotetext{
* Correspondence: apolking@usc.edu.au

${ }^{1}$ Centre for Animal Health Innovation, Faculty of Science, Health, Education and Engineering, University of the Sunshine Coast, Sippy Downs, QLD 4556, Australia

Full list of author information is available at the end of the article
}

growing recognition of the broader biodiversity within this order with the relatively recent proposal of four additional families; "Candidatus Parilichlamydiaceae" [5], "Ca. Piscichlamydiaceae" [6], "Ca. Clavichlamydiaceae" [7] and "Ca. Rhabdochlamydiaceae" [8] that are yet to be accepted. These recently proposed families are largely comprised of bacteria that, to date, predominantly infect fish (Parilichlamydiaceae, Piscichlamydiaceae, Clavichlamydiaceae) or invertebrates (Rhabdochlamydiaceae).

Contrary to the obligate intracellular nature of the chlamydial developmental cycle, many species in the order Chlamydiales can infect multiple hosts across a diverse range of taxa [9]. Beyond the well-described zoonotic potential of the avian pathogen, Chlamydia 
psittaci [10], perhaps one of the best known species with these capabilities is Chlamydia pecorum, a highly prevalent veterinary pathogen. Globally, C. pecorum infects livestock such as sheep, cattle, pigs and goats, and the iconic and nationally vulnerable marsupial, the koala, in Australia [11, 12]. In these hosts, these infections are primarily asymptomatic but can lead to diseases such as pneumonia, arthritis, keratoconjunctivitis and encephalomyelitis in livestock [12] and keratoconjuctivitis, cystitis and reproductive disease in koalas [11]. While within-host routes of transmission are reasonably well characterised for members of the family Chlamydiaceae, much less is known about the transmission of bacteria in other chlamydial families or how cross-host transmission events occur for these pathogens. For the latter, direct contact with infected animals is a risk factor for zoonotic transmission of $C$. psittaci [13] and Chlamydia abortus [14] while indirect contact via environmental contamination from infected animals is also suspected for the former species [15]. Other potential routes of transmission including the use of vectors are largely unknown.

Ticks (Acari: Ixodida) are known to be important vectors in transmitting microorganisms capable of infecting both human and animal hosts. Their ability to feed on such a large range of host species [16] places ticks second to mosquitoes in pathogen transmission worldwide [17]. Studies in the 1970-1980's suggested that Chlamydia may be a naturally occurring pathogen carried by ticks, through experimental infection studies that described multiplication followed by transmission and disease manifestation in cattle $[18,19]$. Further studies were not performed until recently when Chlamydiaceae were identified as dominant taxa in the microbiomes of Japanese ticks, with several Parachlamydia and Simkaniaceae sequences identified [20]. Subsequently, seven Chlamydiales families have been identified across large scale tick screens in Switzerland, Algeria and Finland [21-23]. The most common Chlamydiales detected in these studies were " $\mathrm{Ca}$. Rhabdochlamydia", "Ca. Parachlamydia" and other unclassified and uncultured Chlamydiales, suggesting that the diversity of Chlamydia and Chlamydia-like organisms (CLOs) carried and potentially transmitted by tick species is large and unique.

Seventy tick species have been described in Australia, including 14 soft and 56 hard ticks. Five of these species are suspected of being introduced by humans. Fifty four of these 70 tick species solely feed on wildlife, whereas 16 tick species are known to feed on humans and domestic animals also [24]. Very little is known about Australian ticks in regards to the pathogens they harbour and their potential to transmit these pathogens to humans and wildlife. As of now, only five tick species are known to carry and transmit pathogens including, Queensland tick typhus (Rickettsia australis), transmitted by Ixodes holocyclus and Ixodes tasmani [25]; Flinders Island spotted fever (Rickettsia honei) transmitted by Bothriocroton hydrosauri [26]; as well as Q fever (Coxiella burnetii), previously detected in tick species Haemaphysalis humerosa [27] and Amblyomma t. triguttatum [28]. Novel bacteria belonging to the Rickettsia, Coxiella, Rickettsiella and Borrelia have recently been described from native Australian ticks removed from Australian marsupials $[29,30]$, suggesting the majority of bacterial diversity of Australian ticks is yet to be discovered.

As mentioned previously, Chlamydia is prevalent in Australian wildlife $[11,24]$ and there is also evidence to suggest CLOs have a presence in native marsupials [31-33]. To date, nothing is known about the prevalence of Chlamydia and CLOs in Australian ticks or if they have the potential to vector transmit Chlamydiales between wildlife and other hosts. In the present study, we identified and screened Australian tick species removed from native Australian wildlife hosts to assess the role that these arthropods may have in the transmission of chlamydial infections between Australian wildlife.

\section{Methods}

\section{Tick collection, identification and pooling}

Ticks were opportunistically removed from marsupials and monotremes presenting to collaborating veterinarian and wildlife care centres in New South Wales, Queensland and Tasmania, Australia and stored in 70\% ethanol. Macroscopic residual host tissue collected with the tick during sampling was removed using forceps and $70 \%$ ethanol washing. Morphological characteristics were then used to identify tick species $[34,35]$. Prior to DNA extraction, ticks were then sorted by species and animal host and pooled (1-5 ticks per pool).

\section{Tick dissection and DNA extraction}

Tick dissection and DNA extraction was modified from a previously described QIAGEN quadrisecting protocol [36], to account for the size and density of heavily engorged ticks. Individual ticks in a pool were rinsed twice with $\mathrm{dH}_{2} \mathrm{O}$, then air dried for $10 \mathrm{~min}$. Dissections were carried out by cutting anteriorly to posteriorly down the middle of the hypostome then on a 90 degree angle directly under coxa IV. This tick section was then finely diced and repooled into a microcentrifuge tube with sections from the remaining ticks in each pool for DNA extraction. Sterile instruments were used for each individual dissection. Using the QIAmp DNA mini kit (QIAGEN, Victoria, Australia) tick pools were lysed in $260 \mu \mathrm{l}$ ATL buffer and $20 \mu \mathrm{l}$ Proteinase $\mathrm{K}$ at $56^{\circ} \mathrm{C}$ for $48 \mathrm{~h}$ vortexing occasionally and the DNA extraction was completed using the 'DNA purification from tissues' protocol as per the manufacturer's instructions. DNA was stored at $-20{ }^{\circ} \mathrm{C}$ until further use. 
Chlamydiales PCR amplification, purification and sequencing An 800 bp fragment of the 16S rRNA gene partially covering the Chlamydiales signature sequence was amplified by conventional PCR to screen ticks for Chlamydiales $[5,6]$. The reaction was made up to a final volume of $50 \mu \mathrm{l}$ containing $25 \mu \mathrm{l}$ of Amplitaq Gold 360 master mix (Life Technologies, Victoria, Australia), $1.5 \mu \mathrm{l}$ of each primer 16SIGF ( $5^{\prime}$-CGG CGT GGA TGA GGC AT-3') and 806R (5'-GGA CTA CCA GGG TAT CTA AT-3') and $4 \mu$ l of template DNA. Thermocycler conditions used were as previously described [5]. Negative (no template and $\mathrm{dH}_{2} \mathrm{O}$ ) and positive (C. pecorum PM13 cultured isolate from an Australian koala) controls were included in each amplification assay. At least $5016 \mathrm{~S}$ rRNA copies of chlamydial DNA can be reliably detected with this assay (data not shown). PCR product was purified using the Roche High Pure PCR Product Purification Kit (Roche, New South Wales, Australia) following the manufacturer's instructions. Purified PCR products were di-deoxy sequenced by Macrogen Inc. (Seoul, Korea) in both directions.

\section{Sequence and phylogenetic analysis}

Chromatograms of forward and reverse sequences were aligned in the Geneious R9.1.3 software package [37]. A consensus sequence was derived from each alignment and trimmed to the maximum length possible. Consensus sequences and GenBank representatives of the order Chlamydiales were then aligned in Geneious R9.1.3 using the ClustalW plugin with default parameters [38]. The alignment comprised 44 sequences trimmed to a length of $663 \mathrm{bp}$ and a Bayesian phylogeny was constructed in Geneious R9.1.3 using the MrBayes plugin [39] under the HKY85 substitution model. Run parameters included four Markov chain Monte Carlo (MCMC) chains with a million generations, sampled every 3,000 generations, and with the first 100,000 trees discarded as 'burn-in'.

\section{Predicted prevalence of Chlamydiales infections of individual ticks}

Chlamydiales prevalence for individual ticks was calculated using maximum likelihood estimates with a confidence interval of 0.95 , following previously described methods [21]. Pool size and pool PCR positivity data are used to estimate an individual Chlamydiales prevalence in ticks as well as a minimum and maximum prevalence rate.

\section{Results}

\section{Tick species identified from Australian wildlife}

Overall, 438 adult female engorged ixodid ticks comprised of seven species were identified from ten marsupial hosts and one monotreme host species. Adult female ticks were the most prevalent tick opportunistically removed from animals in this study. The number of male ticks and nymphs removed from animals was unfortunately limited. Due to the low numbers and difficulties in morphological identification to species of male ticks and nymphs, these specimens were excluded from this study. The wildlife host and tick species, number and location (Australian state) are presented in Additional file 1: Table S1. The most common tick species identified from koalas was $I$. tasmani (300/438; 68.5\%) and I. holocyclus (100/438; 21.9\%). Greater tick species diversity was identified from non-koala marsupial hosts, with I. holocyclus being the most common, followed by Haemaphysalis bancrofti.

\section{Prevalence of Chlamydiales in Australian ticks}

The 438 adult female engorged Ixodidae ticks were distributed into a total of 124 pools ranging between one to five ticks based on tick species and wildlife host, then screened using a pan-Chlamydiales PCR (Table 1). Of these 124 pools, 99 were found to be positive for Chlamydiales DNA. Based on this result, individual I. tasmani ticks have an estimated Chlamydiales prevalence of $26.9 \%$ (minimum prevalence: $17.4 \%$, maximum prevalence: $71.6 \%$ ), while individual $I$. holocyclus ticks were estimated to have a Chlamydiales prevalence of 46.8\% (minimum prevalence: 33\%, maximum prevalence: $61.9 \%$ ). Of these species collected from koalas, the estimated prevalence of individual ticks was $24.0 \%$ (minimum prevalence: $15.3 \%$, maximum prevalence: $73.5 \%$ ). All other tick species and wildlife hosts were $100 \%$ PCR positive for Chlamydiales DNA, although the numbers screened were significantly smaller than for the other two tick species.

\section{Chlamydiales detected in Australian ticks}

To determine the identity of the Chlamydiales detected in the ticks screened in this study, the PCR products of 66 pan-Chlamydiales PCR positive pools were directly sequenced. 53/66 (80.3\%) of the PCR products returned clear sequencing signals to enable BLAST analysis against all available Chlamydiales 16S rRNA gene sequences available in GenBank. Chromatograms for the remaining PCR positive samples were unreadable, despite repeated PCR amplification and sequencing efforts, suggesting multiple Chlamydiales agents are present in these tick pools.

The resulting BLAST analysis revealed 53 chlamydial 16S rRNA gene sequences, comprised of six novel $16 \mathrm{~S}$ rRNA Chlamydiales genotypes consistent with new strains, species or genera within the order Chlamydiales, based on previously described taxonomic cut-offs specific to the order Chlamydiales [2, 40] (Table 2). Interestingly, we did not identify any $16 \mathrm{~S}$ rRNA sequences that were identical to those previously described for species in the order Chlamydiales, most notably for members of the Chlamydiaceae, such as C. pecorum, a species known to infect the hosts that these ticks were removed from. 
Table 1 Estimated prevalence of Chlamydiales infections in ixodid ticks removed from Australian wildife based on a maximum likelihood analysis

\begin{tabular}{|c|c|c|c|c|c|c|}
\hline & $\begin{array}{l}\text { No. of } \\
\text { ticks }\end{array}$ & $\begin{array}{l}\text { No. of } \\
\text { pools }\end{array}$ & $\begin{array}{l}\text { No. of PCR } \\
\text { positive pools (\%) }\end{array}$ & $\begin{array}{l}\text { Estimated prevalence } \\
\text { in individual ticks \% }\end{array}$ & $\begin{array}{l}\text { Minimum } \\
\text { prevalence (\%) }\end{array}$ & $\begin{array}{l}\text { Maximum } \\
\text { prevalence }(\%)^{\mathrm{b}}\end{array}$ \\
\hline \multicolumn{7}{|l|}{ Tick species } \\
\hline 1. tasmani & 310 & 73 & $54(73.9)$ & 26.9 & 17.4 & 71.6 \\
\hline I. holocyclus & 112 & 35 & $29(82.9)$ & 46.8 & 33 & 61.9 \\
\hline I. ornithorhynchi & 2 & 2 & $2(100)$ & na & na & na \\
\hline H. bancrofti & 10 & 10 & $10(100)$ & na & na & na \\
\hline H. longicornis & 1 & 1 & $1(100)$ & na & na & na \\
\hline H. humerosa & 1 & 1 & $1(100)$ & na & na & na \\
\hline B. auruginans & 2 & 2 & $2(100)$ & na & na & na \\
\hline \multicolumn{7}{|l|}{ Wildlife host } \\
\hline Koala (Phascolarctos cinereus) & 400 & 86 & $61(70.9)$ & 24 & 15.25 & 73.5 \\
\hline Bare nosed wombat (Vombatus ursinus) & 5 & 5 & $5(100)$ & na & na & na \\
\hline Eastern grey kangaroo (Macropus giganteus) & 9 & 9 & $9(100)$ & na & na & na \\
\hline Red necked wallaby (Macropus rufogriseus) & 3 & 3 & $3(100)$ & na & na & na \\
\hline Spotted tail quoll (Dasyurus maculatus) & 4 & 4 & $4(100)$ & na & na & na \\
\hline Long nosed bandicoot (Perameles nasuta) & 3 & 3 & $3(100)$ & na & na & na \\
\hline Platypus (Ornithorhynchus anatinus) & 2 & 2 & $2(100)$ & na & na & na \\
\hline Squirrel glider (Petaurus norfolcensis) & 2 & 2 & $2(100)$ & na & na & na \\
\hline Short eared possum (Trichosurus caninus) & 1 & 1 & $1(100)$ & na & na & na \\
\hline Brush tail possum (Trichosurus vulpecula) & 7 & 7 & $7(100)$ & na & na & na \\
\hline Ring tailed possum (Pseudocheirus peregrinus) & 2 & 2 & $2(100)$ & na & na & na \\
\hline
\end{tabular}

Abbreviation: na not applicable; pools only consisted of one individual tick

${ }^{a}$ The minimum prevalence in individual ticks is calculated on the assumption only one individual tick per Chlamydiales positive pool is infected

${ }^{b}$ The maximum individual prevalence is similarly calculated on the assumption every individual tick in a PCR positive pool is infected

Based on BLAST and subsequent phylogenetic analysis (Fig. 1), the novel 16S rRNA Chlamydiales genotypes identified in this study were predicted to be associated with the "Ca. Rhabdochlamydiaceae" and Simkaniaceae families. The most prevalent of these sequences, Genotype 1 (KX774315), represented nearly half $(26 / 53 ; 49.1 \%)$ of all the sequences retrieved and was identified in ticks of the genus Ixodes (I. tasmani, I. holocyclus and I. ornithorhynchi) from koala, brushtail possum and platypus hosts. BLAST comparisons revealed that this genotype has $96 \%$ similarity to "Ca. Rhabdochlamydia porcellionis" (AY223862.1), suggesting that, based on current taxonomic classifications, it belongs to a previously undescribed species within the genus " $\mathrm{Ca}$. Rhabdochlamydia". Consistent with this BLAST analysis, this sequence clustered within the " $\mathrm{Ca}$. Rhabdochlamydiaceae", but formed an independent novel lineage from "Ca. Rhabdochlamydia porcellionis" with posterior probability (pp) support of 1 .

Table 2 Abundance of novel Chlamydiales genotypes in tick species and tick hosts

\begin{tabular}{|c|c|c|c|}
\hline Genotype & Tick species (No.) & Tick host (No.) & BLAST ID (\% similarity) \\
\hline 1 & $\begin{array}{l}\text { I. tasmani (23); I. holocyclus (2); } \\
\text { I. ornithorhynchi (1) }\end{array}$ & Koala (24); Brushtail possum (1); Platypus (1) & $\begin{array}{l}\text { "Ca. Rhabdochlamydiaceae porcellionis" } \\
\text { AY223862.1 (96\%) }\end{array}$ \\
\hline 2 & $\begin{array}{l}\text { I. tasmani (7); I. holocyclus (3); } \\
\text { I. ornithorhynchi (1); H. bancrofti } \\
\text { (5); H. longicornis (1) }\end{array}$ & $\begin{array}{l}\text { Koala (6); Red necked wallaby (1); Brushtail } \\
\text { possum (2); Platypus (1); Eastern grey kangaroo (5); } \\
\text { Bare nosed wombat (1); Ringtailed possum (1) }\end{array}$ & "Ca. Fritschea eriococci" AY140911.1 (99\%) \\
\hline 3 & I. tasmani (4); I. holocyclus (1) & Koala (5) & $\begin{array}{l}\text { "Ca. Rhabdochlamydiaceae porcellionis" } \\
\text { AY223862.1 (98\%) }\end{array}$ \\
\hline 4 & I. tasmani (1); H. humerosa (1) & Long nose bandicoot (2) & "Ca. Fritschea eriococci" AY140911.1 (99\%) \\
\hline 5 & 1. holocyclus (2) & Spotted tail quoll (1); Brushtail possum (1) & "Ca. Fritschea eriococci" AY140911.1 (99\%) \\
\hline 6 & 1. tasmani (1) & Koala (1) & $\begin{array}{l}\text { "Ca. Rhabdochlamydiaceae" bacterium } \\
\text { FJ976099.1 (92\%) }\end{array}$ \\
\hline
\end{tabular}




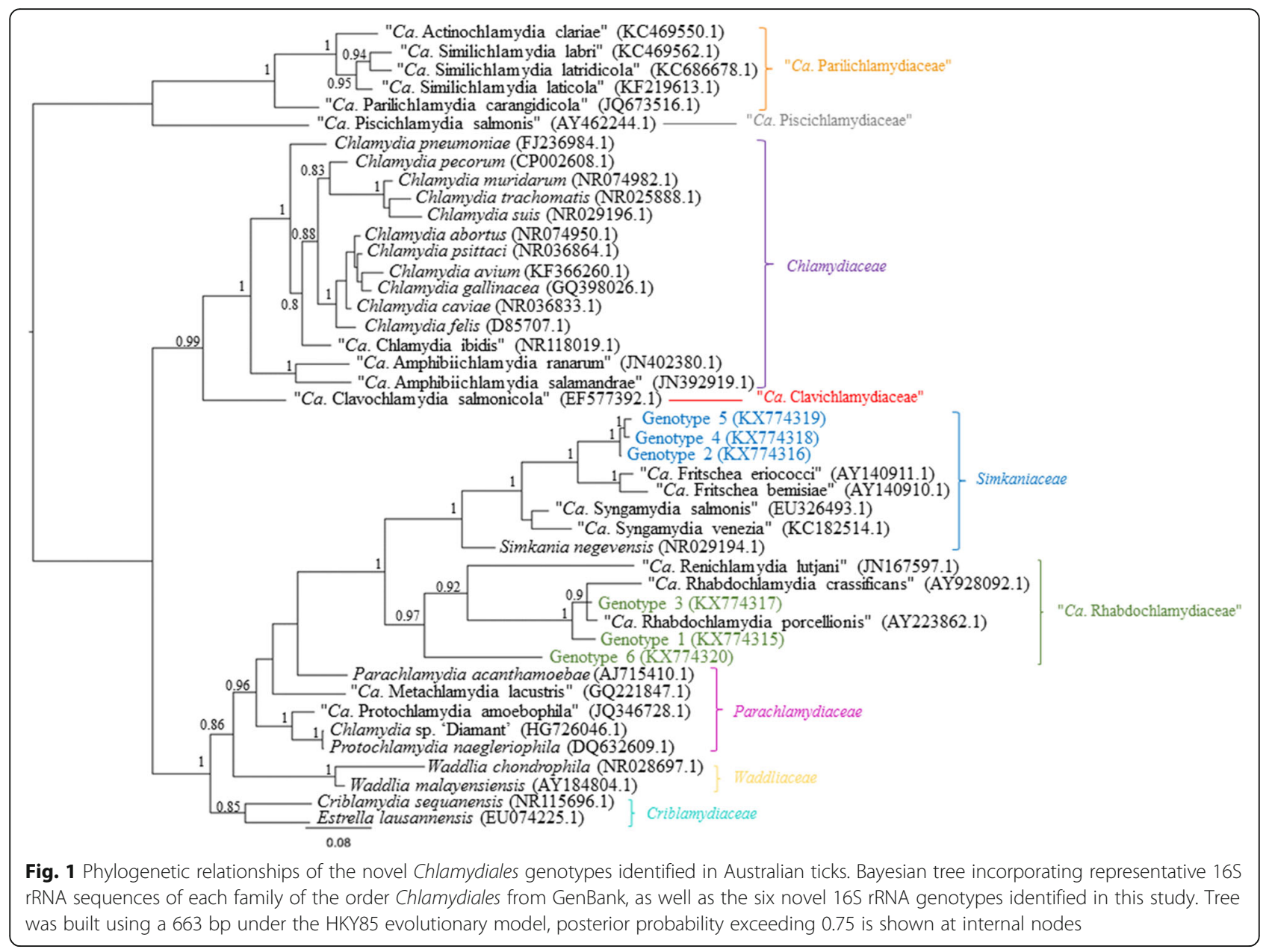

The second most prevalent of these sequences was Genotype 2 (KX774316), which represented just under a third $(17 / 53 ; 32 \%)$ of all the sequences retrieved. Genotype 2 was identified in ticks of the genera Ixodes and Haemaphysalis (I. tasmani, I. holocyclus, I. ornithorhynchi, H. longicornis and $H$. bancrofti) from koalas and a variety of other marsupials (brushtail possum, red necked wallaby, eastern grey kangaroo, ringtail possum and wombat) and monotremes (platypus) examined. BLAST comparisons revealed this genotype has $99 \%$ similarity to " $\mathrm{Ca}$. Fritschea eriococci" (AY140911.1), indicating that the sequences detected potentially belong to strains related to this previously described chlamydial species. This relationship is demonstrated in the phylogeny where there is strong support (pp 1) for Genotype 2 branching off " $\mathrm{Ca}$. Fritschea eriococci" (AY140911.1) as a distinct lineage (Fig. 1).

The third most prevalent of these sequences was Genotype 3 (KX774317), representing almost one fifth (5/53; 9.4\%) of the sequences retrieved. This particular genotype was identified only from I. tasmani and I. holocyclus removed from koalas. BLAST comparisons revealed this genotype has $98 \%$ similarity to " $\mathrm{Ca}$. Rhabdochlamydia porcellionis" (AY223862.1), which would suggest that these sequences belong to a previously undescribed strain belonging to " $\mathrm{Ca}$. Rhabdochlamydia porcellionis". Phylogenetically, this novel genotype sits between two previously proposed species in the genus " $\mathrm{Ca}$. Rhabdochlamydia" (pp 0.9; Fig. 1).

Like Genotype 2, Genotypes 4. (KX774318) and 5 (KX774319) were also found to have 99\% similarity to "Ca. Fritschea eriococci" (AY140911.1), following BLAST analysis, indicating that the sequences detected potentially belong to strains related to this previously described chlamydial species. Less than $1 \%$ dissimilarity separate these three novel 16S rRNA genotypes with four single nucleotide polymorphisms found between Genotypes 2 and 4 and five single nucleotide polymorphisms between Genotype 5 and Genotypes 2 and 4. The relationship between Genotypes 2, 4 and 5 to "Ca. Fritschea eriococci" (AY140911.1) was strongly supported (pp 1) in the phylogeny (Fig. 1). Genotype 4 was identified in only two (3.7\%) of all the sequences retrieved, one from an $I$. tasmani and one from an H. humerosa tick, both removed from long nosed bandicoot hosts exclusively. 
Genotype 5 was identified in two sequences $(2 / 53$; 3.7\%) overall, from two $I$. holocyclus ticks removed from a spotted tail quoll and brushtail possum, respectively.

Genotype 6 (KX774320), was identified from only one pool of $I$. tasmani ticks removed from koalas. BLAST comparisons revealed this genotype has $92 \%$ similarity to "Ca. Rhabdochlamydia porcellionis" (AY223862.1), consistent with it coming from a novel bacteria in a new genus that is closely related to the "Ca. Rhabdochlamydia". This genus-level relationship was strongly supported in the phylogeny (pp 0.97; Fig. 1).

\section{Genotype diversity across tick species}

An analysis of the tick host range of these novel Chlamydiales revealed that tick species within the genus Ixodes harbour a diverse range of novel Chlamydiales (Fig. 2), whereas ticks of the genus Haemaphysalis ( $H$. bancrofti, $H$. longicornis and $H$. humerosa) each only carried one novel chlamydial genotype (Fig. 2). The most prevalent koala tick species I. tasmani, carried the most genotypic diversity with five of the six genotypes cumulatively identified in this species, with Genotype 1 dominating the sampling, totalling $63 \%$ of the diversity. Ixodes holocyclus, the second most prevalent koala tick species and the most prevalent non-koala marsupial tick species carried three of the six novel genotypes, all with a relatively equal abundance. The two platypus ticks, I. ornithorhynchi both carried a different genotype.

\section{Discussion}

Australian ticks have previously been found to be a rich reservoir of novel bacteria belonging to otherwise well-known families of bacterial pathogens. A panChlamydiales order specific $16 \mathrm{~S}$ rRNA PCR screening strategy provided molecular evidence that Australian ticks parasitising native Australian wildlife carry a diverse range of novel bacteria from the order Chlamydiales.

\section{Australian wildlife ticks}

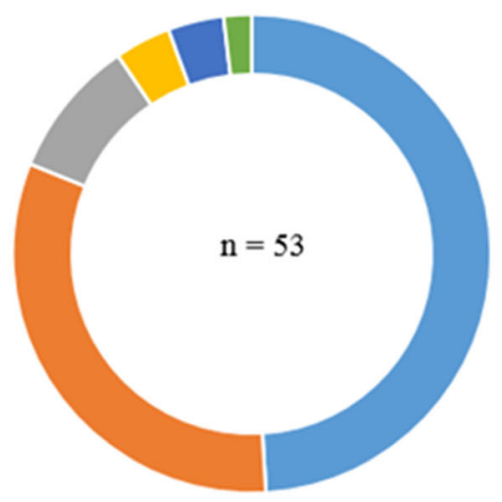

b

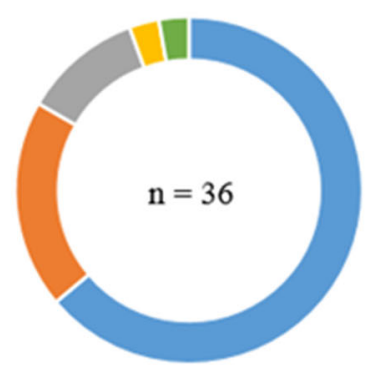

I. holocyclus

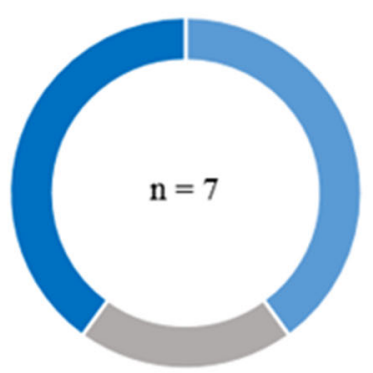

\section{I. ornithorhynchi}

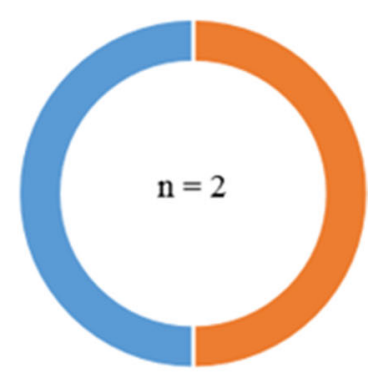

Genotypes: $=1 \quad=2 \quad=3 \quad 4 \quad=5 \quad \approx 6$

Fig. 2 Distribution of novel Chlamydiales genotypes amongst Australian ticks. a Doughnut chart displays the number of sequences retrieved from each Chlamydiales genotype within Australian ticks removed from native wildlife. b Doughnut charts displays the number of sequences retrieved from each Chlamydiales genotype between Australian tick species removed from wildlife that cumulatively carried more than one genotype 
The results of this study indicate that, like previous studies of ticks from Switzerland, Algeria and Finland [21-23], Australian tick species are common hosts for the order Chlamydiales. The percentage of Chlamydiales PCR positive pools and estimated individual prevalence rates in adult tick species I. tasmani and I. holocyclus were significantly higher than that described in previous large-scale investigations of ticks performed in Switzerland $[21,22]$ and Finland [23], however. Although not representative given the limited sample sizes, the Chlamydiales prevalence in the Australian ticks examined here was also significantly higher in the five individually screened tick species with $100 \%$ positivity, compared with individually screened Algerian ticks with only $45 \%$ positivity [22]. These findings suggest that Chlamydiales infections are present in Australian tick species with the likelihood that more than one tick per pool is infected with Chlamydiales. As the majority of the sequences retrieved were of high quality, it is reasonable to suggest that when a pool is positive, more often than not, multiple individual ticks within that pool are infected with the same Chlamydiales bacteria. In order to estimate the true prevalence and rate of infection, a larger sample size and individual tick screening is required.

Interestingly, only novel Chlamydiales $16 \mathrm{~S}$ rRNA genotypes were retrieved from the seven Australian tick species screened in this study. Of the six novel 16S rRNA genotypes identified, three were associated with the family "Ca. Rhabdochlamydiaceae" and three with the family Simkaniaceae. Whereas in previous tick studies, molecular evidence for six Chlamydiales families was retrieved from two Switzerland surveys, five Chlamydiales families from the Finnish survey and four Chlamydiales families from the Algerian survey [21, 22]. On all three of these occasions, the Parachlamydiaceae, "Ca. Rhabdochlamydiaceae", Criblamydiaceae families and unclassified Chlamydiales were described, with Parachlamydiaceae and "Ca. Rhabdochlamydiaceae" being the most abundant taxa. Members of the Simkaniaceae were also identified in both Switzerland surveys but, in contrast to our study, at a much lower abundance. The differences in Chlamydiales composition and prevalence observed in Australian ticks is potentially influenced by four factors: (i) the geographical isolation of Australia, giving rise to a unique evolution of arthropods; (ii) therefore the opportunity for a distinct lineage of Australian Chlamydiales; (iii) unique native Australian marsupial and monotreme wildlife, which could harbour their own Chlamydiales species; and (iv) the amplification and sequencing approach used is this study. In terms of the latter, a higher resolution of Chlamydiales species identity present in ticks was achieved by PCR amplification and sequencing of a longer fragment of the 16S rRNA Chlamydiales signature sequence. Previous studies relied upon a smaller 207-215 bp fragment, which only enabled confident identification to the family or genus level, and produced high numbers of unclassified Chlamydiales; almost equal to the most prevalent taxa $[21,22]$. It is plausible to consider that if additional $16 \mathrm{~S}$ rRNA gene sequence information had been obtained from these latter screens greater resolution of sequence identity would have been obtained, resulting in higher levels of novel chlamydial diversity, as evidenced in this study.

The identification of multiple diverse " $\mathrm{Ca}$. Rhabdochlamydiaceae"-associated genotypes in our ticks is consistent with previous reports for members of this proposed family. The founding members of this family are two species of the genus "Ca. Rhabdochlamydia”, “Ca. R. porcellionis" and "Ca. R. crassificans", and these two species were identified from arthropods, a woodlouse and cockroach, respectively $[8,41]$. The only other member of the family " $\mathrm{Ca}$. Renichlamydia lutjani”, was identified in blue stripped snapper [42]. In the most recent Swiss tick screen, " $\mathrm{Ca}$. Rhabdochlamydiaceae" were the dominant bacteria in the order Chlamydiales identified with chlamydial loads that probably reflect stable replication of these bacteria in their arthropod hosts [21]. The successful amplification and identification of additional novel " $\mathrm{Ca}$. Rhabdochlamydiaceae" again in this study suggests that members of this family are primarily bacterial parasites of invertebrate hosts. Highlighting that we have only just begun to reveal the level of biological diversity within this family, as revealed in a recent metagenomic study of the Chlamydiales that predicted the " $\mathrm{Ca}$. Rhabdochlamydiaceae" to be the most diverse and species rich of the nine known and proposed chlamydial families [43]. While the clinical significance of these bacteria on higher eukaryotes is unclear, further study of the biological diversity within this order, in particular, comparisons of the "Ca. Rhabdochlamydiaceae" infecting different Ixodes tick species from the northern and southern hemisphere, will provide a rich insight into the evolution and adaptation of CLOs to their arthropod hosts.

In contrast to the presence of the Rhabdochlamydiaceae in ticks in this study, the identification of multiple Simkaniaceae-associated genotypes is unexpected given the larger host range of this family. The founding species in this family is the human associated Simkania negevensis [44], whereas the two "Ca. Syngnamydia" species were identified in fish $[45,46]$. Two other proposed species have also been described, "Ca. Fritschea eriococci" and " $\mathrm{Ca}$. Fritschea bemisiae", identified from a scale insect and a whitefly insect, respectively [47]. Despite the fact that the Simkaniaceae was not a highly abundant family in previous studies [21, 22], our Simkaniaceae genotypes made up nearly $40 \%$ of sequences resolved in this study with Genotype 2 being the second most prevalent. It was also interesting to note that these genotypes clustered primarily with the previously described arthropod Simkaniaceae, suggesting that " $\mathrm{Ca}$. Fritschea"-related bacteria, as a subset of the 
broader diversity in this family, might be primarily arthropod parasites. Downstream detailed biological comparisons between these bacteria and those in the " $\mathrm{Ca}$. Rhabdochlamydia" might reveal key mechanisms that are required for survival in arthropods.

Surprisingly, no genus Chlamydia sequences were identified from this screen of Australian wildlife ticks despite 400 of these ticks being removed from koalas in areas where $C$. pecorum is considered to be endemic. Based on current data, the Chlamydiaceae were only identified in very low numbers in Algerian ticks [22] and as a minor contributor to the dominant taxa in the microbiome of two pools of Japanese ticks, further suggesting the genus Chlamydia is not common among arthropods. Observations from a recent Swiss study [21] describe very low loads of Chlamydiaceae bacteria $\left(<10^{2} 16 \mathrm{~S}\right.$ rRNA copies/ $\left.\mu \mathrm{l}\right)$ compared to loads of up to $10^{6}$ copies/ $\mu$ l for " $\mathrm{Ca}$. Rhabdochlamydiaceae" sequences via $\mathrm{qPCR}$, raising questions over whether ticks may be stable hosts for replication of Chlamydiaceae. The assay used in this Chlamydiales screen can reliably detect chlamydial DNA down to at least $5016 \mathrm{~S}$ rRNA copies (data not shown) so it is unlikely that we failed to detect low levels of Chlamydiaceae DNA if they were present. Based on our failure to detect Chlamydiaceae DNA in any of the tick pools screened in this study, it is unlikely that Australian tick species are acting as vectors of C. pecorum between koalas or other animals such as livestock. However, it is interesting to note that there is molecular evidence that native Australian marsupials carry a range of other bacteria in the order Chlamydiales [31, 33, 48]. Sequences of the Parachlamydiaceae and Waddliaceae were identified from non-koala marsupials [31] as well as distinct novel lineage of CLOs from koalas [48]. Furthermore, the Finnish study revealed CLOs from biopsies of human skin with a suspected tick bite were very similar to CLOs carried by Finnish ticks, suggesting that ticks could act as a transmitter of CLOs [23]. Therefore, further investigation into the possibilities of tick to marsupial and marsupial to tick CLO transmission are warranted.

\section{Conclusions}

Novel Chlamydiales genotypes were detected in a screen of 438 native Australian ticks. Six novel genotypes were identified and are predicted to represent new levels of taxonomic diversity in the " $\mathrm{Ca}$. Rhabdochlamydiaceae", likely to be the major taxa found in invertebrates and in the Simkaniaceae, a previously characterised chlamydial family with bacteria that infect a range of eukaryotic hosts. From this study, it is clear that a unique community of CLOs are present in Australian ticks, however the biology of the novel Chlamydiales genotypes identified in this study remains unknown. Comparative studies of these organisms with tick Chlamydiales from other geographic regions may provide insight into local adaption and early evolution of these pathogens. Furthermore, no Chlamydiaceae were identified from Australian wildlife ticks, suggesting that ticks do not act as a vector transmitter of Chlamydia to wildlife and livestock. The role of arthropods as vectors of CLOs needs to be explored further.

\section{Additional file}

Additional file 1: Table S1. Summary of wildlife host and species, number and location of adult female Ixodidae ticks screened for Chlamydiales in this study. (DOCX $14 \mathrm{~kb}$ )

\section{Abbreviations}

Ca: Candidatus; CLOs: Chlamydia-like organisms

\section{Acknowledgements}

The authors wish to acknowledge the assistance of participants from Port Macquarie Koala Hospital, Endeavour Veterinary Ecology and Australia Zoo Wildlife Hospital for the opportunistic collection of ticks on presenting wildlife. We would like to additionally acknowledge Tamieka Fraser for the collection of tick samples from wombats and Sean Fitzgibbon for the collection of tick samples from quolls. The authors would like to acknowledge the Department of Transport and Main Roads Moreton Bay Rail project team for significant support in sampling koalas from the Moreton Bay koala population. Also we would like to acknowledge Peter Timms for his contribution to study design and manuscript preparation.

\section{Availability of data and materials}

The datasets supporting the conclusions of this article are included within the article and its additional file. Nucleotide sequences obtained from this study were deposited in GenBank under accession numbers KX774315-KX774320.

\section{Funding}

This project was supported by an Australian Research Council Discovery Project Grant awarded to PT and AP (DP130102066).

\section{Authors' contributions}

DB performed tick identification, molecular work, data analyses and was primarily responsible for preparation of the manuscript. HW contributed to tick identification. AG, JL and CF assisted with sample collection. AP conceived the study, assisted with data analysis and drafting of the manuscript. All authors read and approved the final manuscript.

Authors' information

Not applicable.

Competing interests

The authors declare that they have no competing interests.

Consent for publication

Not applicable.

Ethics approval and consent to participate

Tick collection was carried out opportunistically on animals presenting for care or collected as a part of other animal health investigations. The approval to complete tick sampling and Chlamydia screening was sought and approved by the University of the Sunshine Coast Animal Ethics Committee (ANS1539).

\section{Author details}

${ }^{1}$ Centre for Animal Health Innovation, Faculty of Science, Health, Education and Engineering, University of the Sunshine Coast, Sippy Downs, QLD 4556, 
Australia. ${ }^{2}$ Australian Government, Department of Environment and Energy, Australian Biological Resources Study, GPO Box 787, Canberra, ACT 2601, Australia. ${ }^{3}$ Australia Zoo Wildlife Hospital, Steve Irwin Way, Beerwah, QLD 4519, Australia. ${ }^{4}$ Endeavour Veterinary Ecology Pty Ltd, 1695 Pumicestone Rd, Toorbul, QLD 4510, Australia. ${ }^{5}$ Port Macquarie Koala Hospital, Roto House Historic Site, Cnr Lord Street and Roto Place, Port Macquarie 2444, NSW, Australia.

Received: 30 September 2016 Accepted: 19 January 2017 Published online: 26 January 2017

\section{References}

1. Everett KDE. Chlamydia and Chlamydiales: more than meets the eye. Vet Microbiol. 2000;75:109-26.

2. Everett KD, Bush RM, Andersen A. Emended description of the order Chlamydiales, proposal of Parachlamydiaceae fam. nov. and Simkaniaceae fam. nov., each containing one monotypic genus, revised taxonomy of the family Chlamydiaceae, including a new genus and five new species, and standards for the identification of organisms. Int J Syst Bacteriol. 1999;2:415-40.

3. Thomas V, Casson N, Greub G. Criblamydia sequanensis, a new intracellular Chlamydiales isolated from Seine river water using amoebal co-culture. Environ Microbiol. 2006;8(12):2125-35

4. Rurangirwa FR, Dilbeck PM, Crawford TB, McGuire TC, McElwain TF. Analysis of the 16S rRNA gene of microorganism WSU 86-1044 from an aborted bovine foetus reveals that it is a member of the order Chlamydiales: proposal of Waddliaceae fam. nov., Waddlia chondrophila gen. nov., sp. nov. Int J Syst Evol Microbiol. 1999:49(2):577-81.

5. Stride MC, Polkinghorne A, Miller TL, Groff JM, Lapatra SE, Nowak BF. Molecular characterization of "Candidatus Parilichlamydia carangidicola," a novel Chlamydia-like epitheliocystis agent in yellowtail kingfish, Seriola lalandi (Valenciennes), and the proposal of a new family, "Candidatus Parilichlamydiaceae" fam. nov. (order Chlamydiales). Appl Environ Microbiol. 2013;79(5):1590-7.

6. Draghi A, Popov VL, Kahl MM, Stanton JB, Brown CC, Tsongalis GJ, et al. Characterization of "Candidatus Piscichlamydia salmonis" (Order Chlamydiales), a Chlamydia-like bacterium associated with epitheliocystis in farmed Atlantic salmon (Salmo salar). J Clin Microbiol. 2004;42(11):5286-97.

7. Karlsen M, Nylund A, Watanabe K, Helvik JV, Nylund S, Plarre H. Characterization of 'Candidatus Clavochlamydia salmonicola': an intracellular bacterium infecting salmonid fish. Environ Microbiol. 2008;10(1):208-18.

8. Kostanjsek R, Strus J, Drobne D, Avgustin G. 'Candidatus Rhabdochlamydia porcellionis', an intracellular bacterium from the hepatopancreas of the terrestrial isopod Porcellio scaber (Crustacea: Isopoda). Int J Syst Evol Microbiol. 2004:54(Pt 2):543-9.

9. Horn M. Chlamydiae as symbionts in eukaryotes. Ann Rev Microbiol. 2008;62: 113-31.

10. Beeckman DSA, Vanrompay DCG. Zoonotic Chlamydophila psittaci infections from a clinical perspective. Clin Microbiol Infect. 2009;15(1):11-7.

11. Polkinghorne A, Hanger J, Timms P. Recent advances in understanding the biology, epidemiology and control of chlamydial infections in koalas. Vet Microbiol. 2013;165(3-4):214-23.

12. Walker E, Lee EJ, Timms P, Polkinghorne A. Chlamydia pecorum infections in sheep and cattle: A common and under-recognised infectious disease with significant impact on animal health. Vet J. 2015;206(3):252-60.

13. Rehn M, Ringberg H, Runehagen A, Herrmann B, Olsen B, Petersson AC, et al. Unusual increase of psittacosis in southern Sweden linked to wild bird exposure, January to April 2013. Euro Surveill. 2013;18(19):20478.

14. Essig A, Longbottom D. Chlamydia abortus: New aspects of infectious abortion in sheep and potential risk for pregnant women. Curr Clin Microbiol Rpt. 2015;2(1):22-34.

15. Branley JM, Bachmann NL, Jeloccnik M, Myers G, Polkinghorne A. Endemic Australian Chlamydia psittaci strains cluster within the highly virulent $6 \mathrm{bc}$ clade of this important zoonotic pathogen. Sci Rpt. 2016. (in press).

16. Parola P, Raoult D. Ticks and tickborne bacterial diseases in humans: An emerging infectious threat. Clin Infect Dis. 2001;32(6):897-928.

17. de la Fuente J, Estrada-Pena A, Venzal JM, Kocan KM, Sonenshine DE. Overview: Ticks as vectors of pathogens that cause disease in humans and animals. Front Biosci. 2008;13:6938-46.

18. Caldwell HD, Belden EL. Studies of the role of Dermacentor occidentalis in the transmission of bovine chlamydial abortion. Infect Immun. 1973;7(2): 147-51.
19. McKercher DG, Wada EM, Ault SK, Theis JH. Preliminary studies on transmission of Chlamydia to cattle by ticks (Ornithodoros coriaceus). Am J Vet Res. 1980; 41(6):922-4.

20. Nakao R, Abe T, Nijhof AM, Yamamoto $S$, Jongejan F, Ikemura T, Sugimoto C. A novel approach, based on BLSOMs (Batch Learning Self-Organizing Maps), to the microbiome analysis of ticks. ISME J. 2013;7:1003-15.

21. Pilloux L, Aeby S, Gaümann R, Burri C, Beuret C, Greub G. High prevalence and diversity of Chlamydiales DNA within Ixodes ricinus ticks suggest a role of ticks as reservoir and vectors of Chlamydia-related bacteria. Appl Environ Microbiol. 2015;81(1):8177-82.

22. Croxatto A, Rieille N, Kernif T, Bitam I, Aeby S, Péter O, Greub G. Presence of Chlamydiales DNA in ticks and fleas suggests that ticks are carriers of Chlamydiae. Ticks Tick-Borne Dis. 2014:5:359-65.

23. Hokynar K, Sormunen J, Vesterinen E, Partio E, Lilley T, Timonen V, et al. Chlamydia-like organisms (CLOS) in Finnish Ixodes ricinus ticks and human skin. Microorganisms. 2016;4(3):28.

24. Barker SC, Walker AR, Campelo D. A list of the 70 species of Australian ticks; diagnostic guides to and species accounts of Ixodes holocyclus (paralysis tick), Ixodes cornuatus (southern paralysis tick) and Rhipicephalus australis (Australian cattle tick); and consideration of the place of Australia in the evolution of ticks with comments on four controversial ideas. Int J Parasitol. 2014;44(12):941-53.

25. Campbell RW, Domrow R. Rickettsioses in Australia: isolation of Rickettsia tsutsugamushi and R. australis from naturally infected arthropods. Trans $R$ Soc Trop Med Hyg. 1974;68(5):397-402.

26. Stenos J, Graves S, Popov VL, Walker DH. Apnomma hydrosauri, the reptileassociated tick reserviour of Rickettsia honei on Flinders Island, Australia. Am J Trop Med Hyg. 2003;69(3):314-7.

27. Smith DJW, Derrick EH. Studies in the epidemiology of Q fever. Aust J Exp Biol Med. 1940;18(1):1-8.

28. McDiarmid L, Petney T, Dixon B, Andrews R. Range expansion of the tick Amblyomma triguttatum triguttatum, an Australian vector of $Q$ fever. Int J Parasitol. 2000;30(7):791-3.

29. Vilcins I-ME, Old JM, Deane E. Molecular detection of Rickettsia, Coxiella and Rickettsiella DNA in three native Australian tick species. Exp Appl Acarol. 2009;49(3):229-42.

30. Loh SM, Gofton AW, Lo N, Gillett A, Ryan UM, Irwin PJ, Oskam CL. Novel Borrelia species detected in echidna ticks, Bothriocroton concolor, in Australia. Parasit Vectors. 2016;9(1):339.

31. Bodetti TJ, Viggers K, Warren K, Swan R, Conaghty S, Sims C, Timms P. Wide range of Chlamydiales types detected in native Australian mammals. Vet Microbiol. 2003;96:177-87.

32. Kumar S, Kutlin A, Roblin P, Kohlhoff S, Bodetti T, Timms P, Hammerschlag MR. Isolation and antimicrobial susceptibilities of chlamydial isolates from western barred bandicoots. J Clin Microbiol. 2007;45(2):392-4.

33. Warren K, Swan R, Bodetti T, Friend T, Hill S, Timms P. Ocular Chlamydiales infections of western barred bandicoots (Perameles bougainville) in Western Australia. J Zoo Wildl Med. 2005;36(1):100-2.

34. Roberts FHS. Australian Ticks. Australia: Commonwealth Scientific and Industrial Research Organization; 1970.

35. Barker SC, Walker AR. Ticks of Australia. The species that infest domestic animals and humans. Zootaxa. 2014;3816:1-144.

36. Ammazzalorso AD, Zolnik CP, Daniels TJ, Kolokotronis SO. To beat or not to beat a tick: comparison of DNA extraction methods for ticks (Ixodes scapularis). Peer J. 2015;3:e1147.

37. Kearse M, Moir R, Wilson A, Stones-Havas S, Cheung M, Sturrock S, et al. Geneious Basic: an integrated and extendable desktop software platform for the organization and analysis of sequence data. Bioinformatics. 2012;28(12):1647-9.

38. Thompson JD, Higgins DG, Gibson TJ. CLUSTAL W: improving the sensitivity of progressive multiple sequence alignment through sequence weighting, position-specific gap penalties and weight matrix choice. Nucleic Acids Res. 1994;22(22):4673-80.

39. Huelsenbeck JP, Ronquist F. MRBAYES: Bayesian inference of phylogeny. Bioinformatics. 2001;17:754-5.

40. Pillonel T, Bertelli C, Salamin N, Greub G. Taxogenomics of the order Chlamydiales. Int J Syst Evol Microbiol. 2015;65(Pt 4):1381-93.

41. Corsaro D, Thomas V, Goy G, Venditti D, Radek R, Greub G. 'Candidatus Rhabdochlamydia crassificans', an intracellular bacterial pathogen of the cockroach Blatta orientalis (Insecta: Blattodea). Syst Appl Microbiol. 2007;30(3):221-8.

42. Corsaro D, Work TM. Candidatus Renichlamydia lutjani, a Gram-negative bacterium in internal organs of blue-striped snapper Lutjanus kasmira from Hawaii. Dis Aquat Organ. 2012;98(3):249-54. 
43. Lagkouvardos I, Weinmaier T, Lauro FM, Cavicchioli R, Rattei T, Horn M. Integrating metagenomic and amplicon databases to resolve the phylogenetic and ecological diversity of the Chlamydiae. ISME J. 2014;8(1):115-25.

44. Friedman MG, Dvoskin B, Kahane S. Infections with the Chlamydia-like microorganism Simkania negevensis, a possible emerging pathogen. Microbes Infect. 2003;5(11):1013-21.

45. Nylund S, Steigen A, Karlsbakk E, Plarre H, Andersen L, Karlsen M, et al. Characterization of 'Candidatus Syngnamydia salmonis' (Chlamydiales, Simkaniaceae), a bacterium associated with epitheliocystis in Atlantic salmon (Salmo salar L.). Arch Microbiol. 2015;197(1):17-25.

46. Fehr A, Walther E, Schmidt-Posthaus $H$, Nufer L, Wilson A, Svercel M, et al. Candidatus Syngnamydia venezia, a novel member of the phylum Chlamydiae from the broad nosed pipefish, Syngnathus typhle. PLoS One. 2013;8(8):e70853.

47. Everett KDE, Thao M, Horn M, Dyszynski GE, Baumann P. Novel Chlamydiae in whiteflies and scale insects: endosymbionts 'Candidatus Fritschea bemisiae' strain Falk and 'Candidatus Fritschea eriococci' strain Elm. Int J Syst Evol Microbiol. 2005;55(4):1581-7.

48. Devereaux LN, Polkinghorne A, Meijer A, Timms P. Molecular evidence for novel chlamydial infections in the koala (Phascolarctos cinereus). Syst Appl Microbiol. 2003:26:245-53.

\section{Submit your next manuscript to BioMed Central and we will help you at every step:}

- We accept pre-submission inquiries

- Our selector tool helps you to find the most relevant journal

- We provide round the clock customer support

- Convenient online submission

- Thorough peer review

- Inclusion in PubMed and all major indexing services

- Maximum visibility for your research

Submit your manuscript at www.biomedcentral.com/submit 